\title{
Analysis of Factors Affecting Yield to Maturity of Corporate Bonds Traded on Indonesia Stock Exchange 2016 - 2018
}

\author{
Ayu Asih Sintami ${ }^{1}$, Bambang Santosoe Marsoem., Ph. D ${ }^{2}$ \\ ${ }^{1}$ Master of Management, Mercubuana University, Jakarta, Indonesia \\ ${ }^{2}$ Lecturer of Postgraduate, Mercubuana University, Jakarta, Indonesia
}

\begin{abstract}
This study analyzes the influence of the variable Debt Equity Ratio (DER), Maturity, Firm Size and Bond Rating on the Yield To Maturity (YTM) of corporate bonds. The study population consists of corporate bonds traded on the Indonesia Stock Exchange period 2016-2018. The sample selection technique by purposive sampling. The research sample 43 corporate bonds issued by 18 companies from all sectors except the banking and financial sectors. The research analysis method used is descriptive statistics and Common Effect Model (CEM) panel data regression. The results showed that partially the DER variable had no effect on YTM, maturity had a significant positive effect on YTM, Firm Size and Bond Rating significant negative effect on YTM. The implication of this research is that companies need to improve their bond ratings to maintain investor confidence. In addition, is easier for companies with large assets to find external sources of funds through the issuance of bonds. This is because both are proven to have a negative effect on YTM. For further research, is expected to study other variables that affect YTM because the coefficient of determination in this study is $59 \%$, and $41 \%$ is influenced by other variables not explained in this study.
\end{abstract}

Keywords:- Debt to Equity Ratio, Maturity, Firm Size, Bond Rating and Yield To Maturity.

\section{INTRODUCTION}

Bonds are securities issued by a corporation or government company that wants to obtain funds by promising a fixed amount of money (principal or par value) to the holder to be paid at maturity in the future (maturity) accompanied by payment of interest (coupon) periodically (Abundanti and Vikaria, 2013: 163). Based on statistical data on the Indonesian Capital Market processed by the Indonesia Bond Pricing Agency (IBPA), and the Directorate General of Financing and Risk Management of the Ministry of Finance (DJPPR) the value of government bonds and corporate bonds between 2012-2018 is as follows:

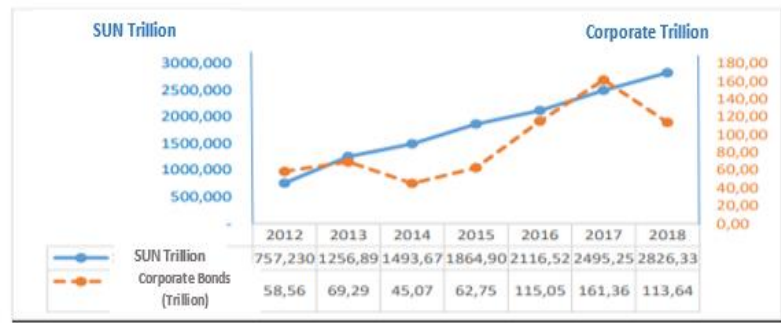

Fig 1: - Comparison of SUN and Corporate Bonds Value Sources: DJPPR and IBPA (2019)

From the above data, the value of corporate bonds in 2012 to 2015 has increased and decreased, so that in 2016 corporate bonds rose rapidly reaching 115.05 Trillion. In 2017 the value of 161.36 trillion increased again and in 2018 it declined again with a value of 113.64 due to global and domestic factors such as before the election and others. One factor that drives the high interest of foreign investors to hunt for corporate bonds is the yield level that is higher than the yield of government bonds. BI noted that in 2012, corporate bond yields ranged from $8-15 \%$, while government bond yields were only $6.4 \%$, so corporate bonds were targeted by investors.

Based on secondary data Historical Data Corporate and Government Bond Yield 2012 - 2018 yield to maturity comparisons of corporate bonds have quite different comparisons. Judging from the annual average, corporate bonds have a fairly large average value of above $9 \%$ compared to government bonds which are only around $7 \%$. One of the yield measurements most often used by investors in investing is Yield To Maturity .

One of the factors that can affect bond yields is leverage. Several previous studies have found several factors that can effect bond yields, namely leverage dam leverage proxied by DER can affect bond yields . Other factors that also may affect the yield of the bonds is the size of the company as well as factors other of its influential on Yield To Maturity is Bond Ratings ( bond rating ) concluded that bond ratings a significant negative effect on yield . Bond ratings show bond quality, which is reflected in bond risk. For investors who tend to be brave for risk ( risk takers ) then tend to be looking for bonds with low ratings to get high yields, while for investors who tend to avoid risk ( risk averter) then tend to look for bonds with 
high ratings because of low risk and yield received also tends to be low .

Based on secondary data of YTM and DER relationship in 2016-2018, the researchers processed that the increase in mean DER in 2018 became 2.16 and the YTM mean decreased in 2017 to $8.85 \%$ which means that this image refers to the opposite picture and based on data Secondary relationship between YTM and Maturity in 2016-2018 which is processed by researchers shows a decrease in mean Maturity in 2016 to 2018 to 3.84 and mean YTM has decreased in 2018 to $8.75 \%$ which means that the maturity graph is positively related to the ytm, because the greater uncertainty of maturity results in high risk, the value of ytm will increase and based on secondary data YTM Relationship and Company Size in 2016-2018 processed by researchers also shows that there is an increase in the mean size of the Company in 201654907 (Billion) annually be 65006
(Billion) and the mean YTM is experiencing a decrease in 2017 to $9.85 \%$. which means that this graph is positively related, where the company's ability to properly manage risk with yields falling. Based on secondary data, the Relationship between YTM and Bond Ratings for 20162018 also shows that bond ratings have fluctuations and the average value of ytm has a negative trend. Bond ratings are negatively correlated with YTM. Companies that have low bond ratings will certainly offer bonds with high yields to attract more interest from investors and provide greater YTM in compensating for the emergence of greater risk.

Several studies related to the effect of DER , Maturity, Company Size and Bond Rating on Yield to Maturity of bonds still have a discrepancy ( research gap) both in terms of the model, the variables that influence it and the results, such as signs and significance, between one researcher and another researcher as can be followed in the table below:

\begin{tabular}{|c|c|c|c|c|c|}
\hline \multirow{2}{*}{ No } & \multirow{2}{*}{ NAME, YEAR } & \multicolumn{4}{|c|}{ INDEPENDENT VARIABLES } \\
\cline { 3 - 5 } & LEVERAGE (DER) & MATURITY & $\begin{array}{c}\text { SIZE OF THE } \\
\text { COMPANY }\end{array}$ & $\begin{array}{c}\text { BOND } \\
\text { RATINGS }\end{array}$ \\
\hline 1 & Surya and Naher, 2011 & (+) Significant & & No effect & No effect \\
\hline 2 & Hapsari, 2013 & (+) Significant & & (+) Significant & \\
\hline 3 & Indarsih, 2013 & & (+) Significant & & No effect \\
\hline 4 & Desnitasari, 2014 & No effect & & No effect & (-) Significant \\
\hline 5 & Aisah and Haryanto, 2012 & (+) Significant & (+) Significant & (-) Significant & (-) Significant \\
\hline 6 & Nariman, 2016 & No effect & & (+) Significant & \\
\hline 7 & Listiawati and & (+) Significant & & No effect & \\
\hline 8 & Paramita, 2018 & & (+) Significant & & (+) Significant \\
\hline 9 & Sari and Abundanti, 2015 & & (+) Significant & & (-) Significant \\
\hline 10 & Faizah, 2019 & No effect & (-) Significant & No effect & (+) Significant \\
\hline
\end{tabular}

Table 1:- Previous Research Gap Research

Source: Processed by researchers

Based on the description of the results of research on the effect of DER, Maturity, Company Size and Bond Rating on Yield to Maturity of bonds has been widely carried out by previous researchers but the results still show inconsistencies. So the authors are interested in reviewing using the four variables. Thus, the author will conduct research under the title" Analysis Of Factors Affecting Yield To Maturity Of Corporate Bonds Traded On Indonesia Stock Exchange 2016-2018 ".

\section{THEORETICAL REVIEW}

\section{A. Bond}

Bonds are long-term contracts where the borrower agrees to pay interest and principal, on a certain date, to the bondholders (Brigham, 2006 ).

The advantage of investing in bonds is earning interest and the possibility of capital gains. Bonds can generally be grouped into: Coupon Bonds, Pure Discount Bonds, and Consols.

In Coupon Bonds, at the end of a certain period the issuer pays interest (coupons), and on the maturity date (pay date) interest + principal (coupon + principal).

$>$ In Pure Discount Bonds, the issuer does not pay a coupon, but at the end of the period pays off the obligation at the face value of the bond.

$>$ At Consols, the issuer pays the coupon every period, but the principal debt is never repaid.

\section{B. Bond Yield}

Bond yield is bond income that can be obtained from bond yields and bond interest. Analysts and investors use several yield measures to determine the returns on bond investments. Bond yield is the most important factor for investors to consider when buying bonds as an investment 
ISSN No:-2456-2165

instrument. Bond investors will calculate how much investment income from the funds bought by the bond using a yield measurement tool (Rahardjo, 2003).

Fabozzi (2000) states that there are two terms in determining yield, namely current yield and yield to maturity. Current yield is the relationship of annual interest coupons to the market price of bonds. YTM is a measure of yield that is widely used because it yields reflects the return to the compound interest rate ( compounded rate of return) is expected investor.

\section{Leverage}

Leverage ratio is one way to measure a company's ability to meet its long-term obligations. The most common leverage ratio is the debt to equity ratio. DER is a leverage ratio that compares total debt with total equity of shareholders. According to Hilda (2013), if leverage is high enough, then it shows the high use of debt, so that it can make the company experiencing financial difficulties and has a risk of bankruptcy that is quite large.

\section{Maturity}

Maturity is the date on which the bondholders will get the principal repayment or Nominal Value of the bonds they hold (OJK, 2018). The maturity period of the bonds varies from 365 days to more than 5 years.

\section{E. Company Size ( Firm Size)}

Grouping companies on the basis of the scale of operations (large or small) can be used by investors as one of the variables in determining investment decisions. Benchmarks that indicate the size of a company, including total sales, average sales levels and total assets (Ferry and Jones, 1979 in Panjaitan, 2004). Large companies generally have large total assets as well so they can attract investors to invest their capital in these companies.

\section{F. Bond Rating}

Bond rating is one of the important factors that affect bond yield because bond rating is the risk scale of all traded bonds. Bond ranking is divided into two ratings, namely investment grade (AAA, AA, A, BBB) and non-investment grade $(\mathrm{BB}, \mathrm{B}, \mathrm{CCC}$, and $\mathrm{D})$.

\begin{tabular}{|c|c|}
\hline $\begin{array}{c}\text { Ranking } \\
\text { symbol }\end{array}$ & Definition \\
\hline AAA & $\begin{array}{c}\text { Debt securities rated idAAA are debt securities } \\
\text { with the highest rating from Pefindo which are } \\
\text { supported by the obligor's superior relative } \\
\text { ability compared to other Indonesian obligors to } \\
\text { meet their long-term financial obligations as } \\
\text { promised. }\end{array}$ \\
\hline A A & $\begin{array}{c}\text { Debt securities with id AA rating having a credit } \\
\text { quality slightly below the highest rating are } \\
\text { supported by the obligor's very strong ability to } \\
\text { meet its long-term financial obligations as } \\
\text { promised, relatively compared to other } \\
\text { Indonesian obligors. }\end{array}$ \\
\hline
\end{tabular}

\begin{tabular}{|c|c|}
\hline A & $\begin{array}{l}\text { Definition of debt securities rated id have a } \\
\text { strong ability to support obligors compared to } \\
\text { other Indonesian obligors to meet their long- } \\
\text { term financial obligations as promised, but are } \\
\text { quite sensitive to changes in adverse business } \\
\text { and economic conditions. }\end{array}$ \\
\hline BBB & $\begin{array}{l}\text { The debt security rating with idBBB rating is } \\
\text { supported by the obligor's adequate ability } \\
\text { relative to other Indonesian debt securities to } \\
\text { meet long-term financial obligations in } \\
\text { accordance }\end{array}$ \\
\hline BB & $\begin{array}{l}\text { Debt securities rated idBB show a relatively } \\
\text { weak obligor's ability to support relative to other } \\
\text { Indonesian debt securities to meet long-term } \\
\text { financial obligations as promised and sensitive } \\
\text { to uncertain and detrimental business, financial } \\
\text { and economic conditions }\end{array}$ \\
\hline B & $\begin{array}{l}\text { Debt securities rated id B show very weak } \\
\text { protection parameters. Although the obligor still } \\
\text { has the ability to meet its long-term financial } \\
\text { obligations, a change in adverse business and } \\
\text { economic conditions will worsen the obligor's } \\
\text { ability to meet its financial obligations }\end{array}$ \\
\hline $\mathrm{CCC}$ & $\begin{array}{l}\text { Debt securities rated CCC CCC indicate debt } \\
\text { securities that are no longer able to meet their } \\
\text { financial obligations and only depend on } \\
\text { improving business and financial conditions }\end{array}$ \\
\hline D & $\begin{array}{c}\text { Debt securities rated id D indicate debt } \\
\text { securities that have failed to pay or the issuer } \\
\text { has stopped trying }\end{array}$ \\
\hline
\end{tabular}

Table 2:- Definition of PT. PEFINDO Source: PT. PEFINDO

\begin{tabular}{|c|c|c|}
\hline Ranking symbol & Indicator & Score \\
\hline AAA & The most superior & 7 \\
\hline A A & Most powerful & 6 \\
\hline A & Strong & 5 \\
\hline BBB & Adequate & 4 \\
\hline BB & Rather weak & 3 \\
\hline B & Weak & 2 \\
\hline CCC & Not capable & 1 \\
\hline D & Failed & 0 \\
\hline
\end{tabular}

Table 3:- Ranking category

Source: PT. PEFINDO

\section{G. Prior Research}

Research conducted Hapsari (2013) who find that the DER and the size of the company's positive and significant impact on the Yield To Maturity. Sari and Abundanti, ( 2015 ) concluded that Maturity and Rating had a positive and significant effect on Yield To Maturity . Kim Chin and Abdullah (2012) found firm size not to Yield To Maturity. Grandes and Peter (2004) found that DER had a positive effect on Yield To Maturity . 
H. Framework
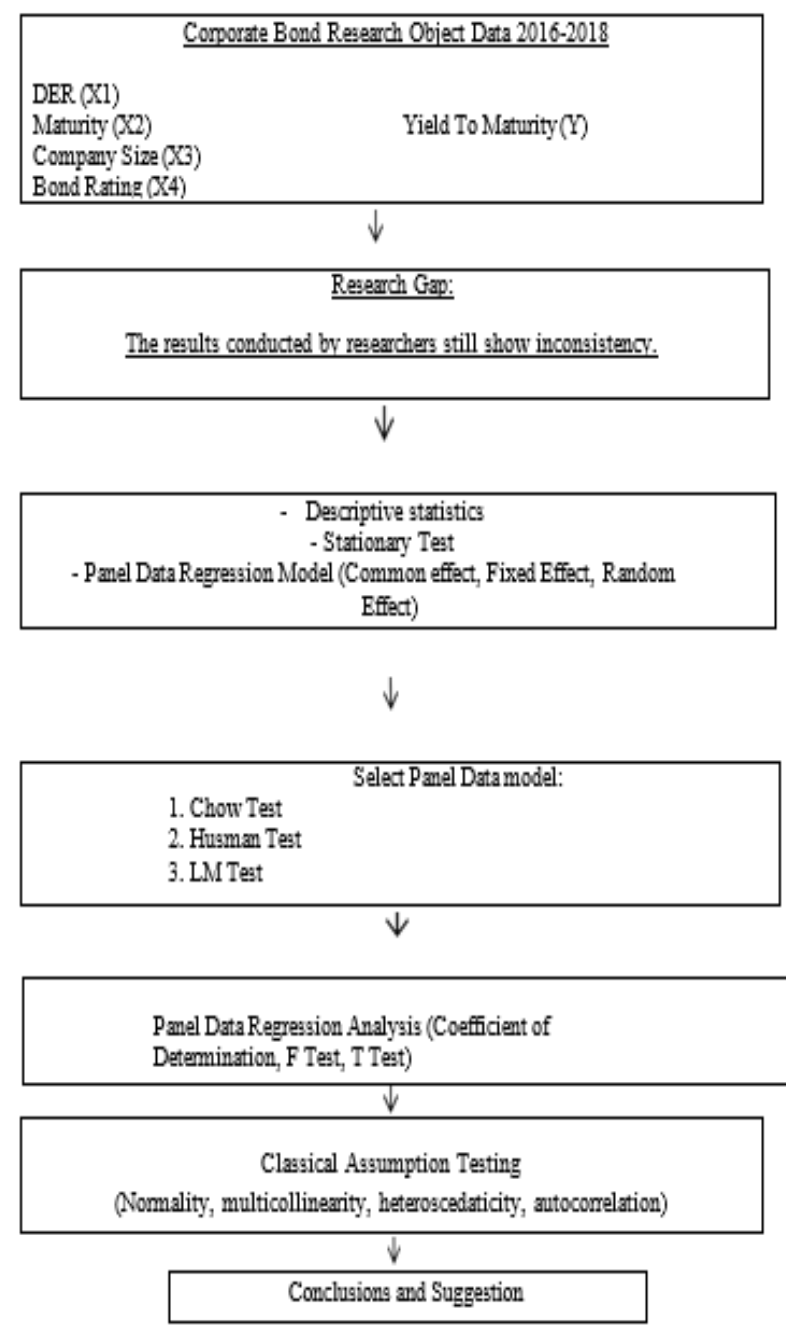

Fig 2:- Conceptual Framework

Source: Processed by researchers

\section{Hypothesis}

Based on the framework that has been dikemu ka kan, the research hypothesis can be formulated as follows:

$>$ H1: DER has a positive effect on Bond Yield

H2: Maturity has a positive effect on bond yields

$>$ H3: Company size has a negative effect on bond yields

D H: Bond rating has a negative effect on Bond Yield.

\section{METHODOLOGY}

This type of research is causality research, namely research that aims to test hypotheses and find out the relationship and influence between two or more variables on other variables

\section{A. Population and Sample}

The population in this study is corporate bonds that are traded and have been listed on the Indonesia Stock Exchange (IDX) during 2016-2018. The method of sampling is purposive sampling. The sample criteria specified are:
Listed corporate bonds traded during 2016-2018 which are not included in the banking, financial and insurance industries .

$>$ Pay a fixed amount of coupons, to ensure that there is no floating rate effect on bond prices .

> Corporate bonds are listed in the bond rating issued by PT. PEFINDO.

$>$ Companies that issue bonds have complete financial statements during the observation period .

Based on the sample criteria above, 81 corporate bonds were obtained from 31 issuing companies as samples.

\begin{tabular}{|c|c|}
\hline No & Company \\
\hline 1 & $\begin{array}{c}\text { PT Sinar Mas Agro Resources and Technology } \\
\text { (SMART) Tbk }\end{array}$ \\
\hline 2 & PT Antam Tbk \\
\hline 3 & PT Indofood Sukses Makmur Tbk \\
\hline 4 & PT Mayora Indah Tbk \\
\hline 5 & PT Agung Podomoro Land Tbk \\
\hline 6 & PT Bumi Serpong Damai Tbk \\
\hline 7 & PT Summarecon Agung Tbk \\
\hline 8 & PT Adhi Karya Tbk \\
\hline 9 & PT Jasa Marga Tbk \\
\hline 10 & PT Indosat Tbk \\
\hline 11 & PT Telekomunikasi Indonesia Tbk \\
\hline 12 & PT AKR Corporindo Tbk \\
\hline 13 & PT Mitra Adiperkasa Tbk \\
\hline 13 & PT Pupuk Indonesia \\
\hline 15 & PT Nippon Indosari Corpindo Tbk \\
\hline 16 & PT Modernland Realty Tbk \\
\hline 17 & PT PP (Persero) Tbk \\
\hline 18 & PT Waskita Karya (Persero) Tbk \\
\hline
\end{tabular}

Table 4: - List of Company Samples

Source: Secondary data processed by the author

\section{B. Data Collection Methods}

The data used in this study are secondary data which includes:

$>$ Data of Corporate Bonds registered and traded during 2016-2018 taken from the Indonesia Stock Exchange website (www.idx.co.id).

$>$ Bond Rating Data for the period of 2016-2018 taken from the official website of PT. Pefindo (www.pefindo.com).

$>$ Information data related to types of bonds registered and traded during 2012018 taken from the website of PT. Kustodian Sentral Efek Indonesia (www.ksei.co.id).

$>$ Price reasonable bond corporation a period of years from 2016 to 
2018 were taken from Indonesia Bond Pricing Agency (www.ibpa.co.id).

$>$ Coupon Value of 2016-2018 bond issuing companies taken from the website of PT. Kustodian Sentral Efek Indonesia (www.ksei.co.id).

$>$ Maturity Period of the 2016-2018 bond issuer taken from the website of PT. Kustodian Sentral Efek Indonesia (www.ksei.co.id).

$>$ Debt to Equity Ratio of 2016-2018 bond issuing companies taken from the Indonesia Stock Exchange website and the company's Financial Statements .

$>$ Company size of companies issuing bonds in 20162018 taken from the Indonesia Stock Exchange website and the company's Financial Statements

\section{Data Analysis Methods}

The data obtained from the results of subsequent studies were analyzed with a panel data regression analysis model that aims to determine the effect of DER, Maturity, Company Size on YTM Bonds. This study uses panel data and data management using Eviews software version 9.

\section{RESULTS AND DISCUSSION}

\section{A. Descriptive Statistics Analysis}

Based on the results of descriptive analysis in the following study

\section{$\operatorname{DER}(\mathrm{XI})$}

$D E R$ has a minimum value of 0.510000 and a maximum of 3.830000 with an average ( mean ) of DER of 1.958062. The standard deviation value indicates a number of 0.972196 .

\section{$>$ Maturity (X2)}

Maturity Period has a minimum value of 1.000000 and a maximum of 24.50000. This shows that the magnitude of the mean ( mean) of the Maturity Period is 4.840930. The standard deviation value shows a figure of 3.878106 .

\section{Company Size (X3)}

Company size has a minimum value of 2,081 billion and a maximum of 179,611 with the mean (mean) of company size being 55,586. The standard deviation value shows a figure of 51,731 .

\section{Bond Rating (X4)}

Bond ratings have a minimum value of 4.000000 and a maximum of 12.00000 , with an average ( mean ) rating of bonds of 9.790698 . The standard deviation value indicates a number of 2.520771 .

\section{Yield To Maturity Bonds (Y)}

During 2016 to 2018 Yield To Maturity $O$ bligation has a minimum value of 7.293000 and a maximum of 11.06300 , with an average (mean) of Yield To Maturity Bonds amounting to 9,089628. The standard deviation value indicates a figure of 0.798230 .
The average value of YTM shows that investment through corporate bonds provides sufficient prospects of high returns. Standard deviations smaller than the mean indicate the data are homogeneous and have a low level of deviation.

\section{B. Panel Data Regression Method}

Following are the results of the test estimating the panel data regression model with the Common Effect Model (CEM), Fixed Effect Model (FEM) and Random Effect Model (REM) approaches :

\section{$>$ Common Effect}

Common Effect Model(CEM) Estimation test results in this study use Eviews 9 with the following results:

- The DER variable (X1) has a positive reggression coefficient of 0.059297 with a p-value (sig) of 0.2177 > $\alpha 0.05$

- the variable maturity (X2) has a positive regression coefficient of 0.125218 with a p-value (sig) of 0.0000 $<\alpha 0.05$.

- The company size variable (X3) has a negative regression coefficient of -0.178769 with pv alue (sig) $0.0027<\alpha 0.05$.

- The Bond Rating (X4) variable has a positive regression coefficient of -0.234000 with a p- value (sig) $0.0000<\alpha$ 0.05 .

- The F-statistic value is 45.05309 with a p-value (sig) of $0.000000<\alpha 0.05$.

- The R square value is 0.594344 or $59.43 \%$

\section{$>$ Fixed Effect Model}

From the results of the fixed effect Model (FEM) test in this study, it can be explained as follows:

- The variable DER (X1) has a positive regression coefficient of 0.059152 with p-value (sig) $0.2227>\alpha$ 0.05 .

- The variable Maturity (X2) has a positive regression coefficient of 0.125106 with a p- value (sig) $0.0000<\alpha$ 0.05 .

- The firm size variable (X3) has a negative regression coefficient of -0.178492 with a p- value (sig) $0.0029<\alpha$ 0.05 .

- Bond Rating variable (X4) has a positive regression coefficient of 0.233772 with a p- value (sig) $0.0000<\alpha$ 0.05 .

- The F-statistic value is 29.57065 with a p-value (sig) $\mathrm{F}$ of $0.000000<\alpha 0.05$.

- The R square value is 0.594537 or $59.45 \%$.

\section{$>$ Random Effect}

From the results of the Random Effect Model (FEM) test in table 4 it can be explained as follows:

- The DER variable (X1) has a positive regression coeficient of 0.034355 with a p-value ( $\mathrm{sig}$ ) of $0.5041>$ $\alpha 0.05$.

- The variable Maturity (X2) has a positive regression coefficient of 0.123617 with a p-val ue (sig) $0.0000<\alpha$ 0.05 . 
- The company size variable (X3) has a negative regression coefficient of -0.179219 with $\mathrm{p}$ - value (sig) $0.0011<\alpha 0.05$.

- The Bond Rating (X4) variable has a positive regression coefficient of -0.229217 with a p- value (sig) $0.0000<\alpha$ 0.05 .

- The F-statistic value is 49.46509 with a p-value (sig) F of $0.000000<\alpha 0.05$.

- The R square value is 0.616656 or $62 \%$

\section{Selection of Regression Models}

In a selection of data processing models used in a study needs to be based on a variety of statistical considerations.

\section{Test Chow}

Chow test is used to select the best model between Common Effect and Fixed Effect. If the value of the cross section $\mathrm{F}$ probability> 0.05 (determined at the beginning as the level of significance or alpha), the model chosen is the Common Effect Model (CEM), but if <0.05, the selected model is the Fixed Effect Model (FEM). The results of the Chow Test in this study use Eviews 9. The Chow test results get the value of the cross section $F$ probability is 0.9717 , thus the appropriate panel data method between the Common Effect Model (CEM) and the Fixed Effect Model (FEM) is the Common Effect Model (CEM). ) because the value of the cross section $F$ probability is 0.9717 which means it is greater than the significance level $\alpha \quad(5 \%)$, then $\mathrm{H} 0$ is accepted. Furthermore, if the Chow Test concludes to choose to use the Common Effect Model (CEM), then there is no need for further tests.

\section{Results of Panel Data Regression Analysis}

Based on the above test, the Random Effect Model (REM) has been chosen. Thus it can be concluded that of the three models (Common Effect Model, Fix Effect Model and Random Effect Model), Random Effect Model (FEM) is better in interpreting panel data regression for this research

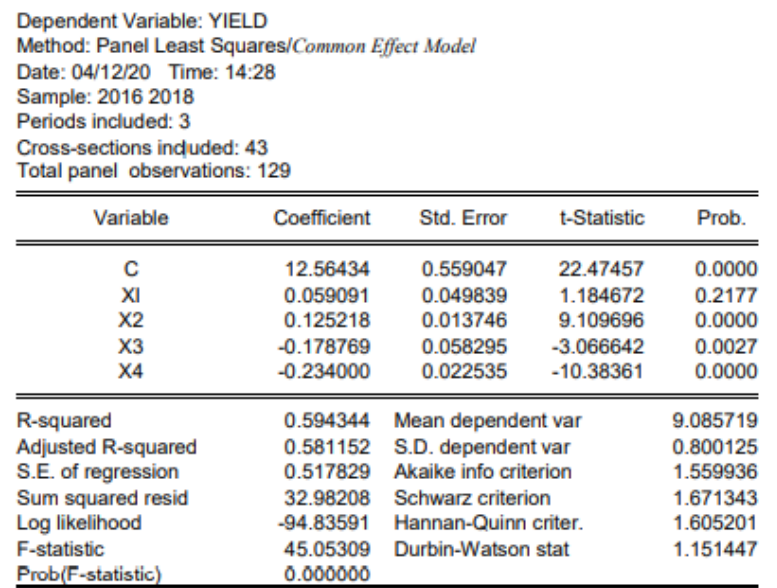

Table 5:- Panel Data Regression Results

Source: Author's data processed, 2020
Based on the table 5, the panel data regression equation is obtained as follows:

$\mathrm{Y}=12.56434+0.059091 \mathrm{X} 1+0.125218 \mathrm{X} 2-$ $0.178769 \times 3-0.234000 \times 4$

From the regression equation it can be concluded as follows:

$>$ The constant coefficient value is 12,56434, meaning that if the DER (X1) Maturity (X2), Company Size (X3), and Bond Rating (X4) variables are zero, then the amount of Yield to Maturity y Bond is 12,56434.

$>$ The regression coefficient value for the DER variable (X1) is positive but not significant. So it has no effect on Yield To Maturity.

$>$ The regression coefficient value of the Maturity Period (X2) variable is positive, namely 0.125218 , meaning that every $1 \%$ increase in Maturity Period (X2) is predicted to increase the bond yield by 0.125218 assuming other variables remain .

$>$ The regression coefficient value of the firm size variable (X3) is negative, which is equal to -0.178769 , meaning that if there is an increase in the company size variable by one unit, the YTM (Y) variable has an increase or vice versa by -0.178769 with the other variables being constant.

The value of the Bond Rating variable regression coefficient (X4) is negative of -0.234000 , meaning that every $1 \%$ increase in Bond Rating (X4) is predicted to increase Yield To Maturity by -0.234000 assuming the other variables remain.

\section{E. Classical Assumption Test}

The classic assumption test in this study consists of tests of normality, multicollinearity, heteroscedasticity, and autocorrelation. If all tests are met, then the analysis model is feasible to use.

\section{Normality}

Test data normality using the Eviews 9 facility, so all variables in this model test show that the above research is normally distributed or it can be said that the requirements for normality can be met. This can be seen from Jarque Bera in this study of 2.496798 with a probability of 0.286964 greater than the 0.05 significance level. Therefore the research is normally distributed, so it can be said that the requirements for normality can be met.

\section{$>$ Multicollinierity}

Based on the multicollinity test results obtained Centered VIF DER $\left(\mathrm{X}_{1}\right)$ Maturity $\left(\mathrm{X}_{2}\right)$, Company Size $\left(\mathrm{X}_{3}\right)$, and Bond Rating $\left(\mathrm{X}_{4}\right)$ values smaller than 10 , it can be concluded in this study that there are no multicollinearity symptoms.

\section{$>$ Heteroscedasticity}

Heteroscedasticity test results with the BreuschPagan-Godfrey Test showed an F-statistic probability value of $0.2100>\alpha(0.05)$ and it can be concluded that there was no heteroscedasticity problem in the research data. 


\section{$>$ Autocorrelation}

The measuring instrument used to detect the presence of autocorrelation in research using the Durbin Watson (DW) test. Based on the results of the autocorrelation test, the value is obtained. The resulting DW from the regression model is 1.151447. Meanwhile, from the DW table with a significance of 0.05 and the amount of data $(\mathrm{n})=129$, and $\mathrm{k}=4$ ( $\mathrm{k}$ is the number of independent variables), the $\mathrm{dU}$ value is 1.7769. 4-du = 2,2231. Looking at the DW and 4-du values, it is concluded that there is no autocorrelation for the regression model.

\section{F. Hypothesis Testing}

\section{Coefficient Determination}

Based on the results of calculations using Eviews 9, the coefficient of determination is obtained R-Squared (R2) of 0.594344 . This shows that the percentage of influence of the independent variable DER (X1) Maturity (X2), Company Size (X3), and Bond Rating (X4) on the dependent variable Yield To Maturity (Y) is 59\%, while the remaining $41 \%$ is influenced by other variables not described in this study.

\section{$>$ F test}

The $\mathrm{F}$ test in this study obtained a statistical value of 45.05309> Ftable 2.45 with a significant $0.000<0.05$, thus $\mathrm{Ho}$ is rejected and $\mathrm{Ha}$ is accepted, meaning that simultaneously there is a positive and significant effect on DER (X1) Maturity (X2), Company Size ( X3), and Bond Rating (X4) to Yield To Maturity (Y).

\section{Test $t$}

Partial hypothesis proposed in this study will be performed using t-test, if the value of $t_{\text {arithmetic }}$ greater than $\mathrm{t}$ table indicates acceptance of the hypothesis. $\mathrm{T}$ count value can be seen in the regression results and $t_{\text {table values obtained }}$ through sig. $\alpha=0.05$

Based on the results of these tests it can be explained the influence between variables as follows:

$>\operatorname{DER}(\mathrm{X} 1)$ has a t-statistic value of $1.184672<\mathrm{t}$ table 1.979 with a significance value of $0.2177>0.05$, so H0 is accepted and $\mathrm{Ha}$ is rejected, meaning that DER has no effect on Bond Yield to Maturity.

> The variable Maturity (X2) has a t-statistic value of 9.109696> t table 1.979 with a significant value of $0.0000<0.05$ then $\mathrm{H} 0$ is rejected and Ha is accepted, which means that there is a positive and significant effect of Maturity (X2) on the Yield to Maturity of Bonds

$>$ Company Size (X3) has a tstatistic value of $-3.066642>$ ttable -1.979 with a significant value of $0.0011<0.05$, so $\mathrm{HO}$ is rejected and $\mathrm{Ha}$ is accepted, meaning that there is a significant negative effect Company Size on Bond Yield to Maturity.

> The Bond Rating variable (X4) has a tstatistic value of $10.38361>$ ttable -1.979 with a significant value of $0.0000<0.05$, so $\mathrm{HO}$ is rejected and Ha is accepted, meaning that there is a negative and significant effect of Bond Rating on the yield to bond maturity.

\section{G. Discussion}

\section{$>$ Effect of DER on Yield to Maturity}

Based on the results of statistical analysis of the DER variable $(\mathrm{X} 1)$, it was obtained a positive DER value of 0.059091 with a significance of 0.2177 greater than the $\mathrm{p}$ value: 0.05 , so it can be concluded that DER has no effect on Bond Yield to Maturity, so the first alternative hypothesis is rejected. The rejection of this hypothesis is not in accordance with the results of research conducted by (Surya \& Nasher, 2011; Hapsari, 2013) that the leverage proxied by DER can have a significant effect on bond yields.

\section{> Effect of Maturity Period on Yield to Maturity}

Based on the results of statistical analysis of the term of maturity variable, the significance value is 0.0000 .The significance value is smaller than 0.05 and the regression coefficient is positive 0.125218 so that it can be concluded that the Maturity Period has a positive and significant effect on Yield To Maturity, so the second alternative hypothesis received. This hypothesis is supported by Indarsih, 2013. Where maturity has a positive effect on bond yield to maturity. The positive relationship between maturity and Yield To Maturity is due to the longer the maturity period, the higher the risk of the bonds, so that investors will signal a greater Yield To Maturity.

\section{Effect of Company Size on Yield to Maturity}

Based on the results of the statistical analysis of the firm size variable, the significance value is 0.0027 . The significance value is less than 0.05 and the regression coefficient is negative -0.178769 so that it can be concluded that company size has a significant negative effect on Yield To Maturity, so the third alternative hypothesis is accepted. Empirically, the results of this study are consistent with the research results of Thompson and Vaz (1990), Ibrahim (2008), Wibowo (2016).

\section{Effect of Bond Rating on Yield to Maturity}

Based on the results of the statistical analysis of the Bond Rating variable, the significance value is 0.0000 . The significance value is less than 0.05 and the regression coefficient is negative -0.234000 , so it can be concluded that the Bond Rating has a negative and significant effect on Bond yield, so the fourth alternative hypothesis is accepted. The results of this study also support research conducted by Desnitasari, 2014 Aisah and Haryanto, 2012 Sari and Abundanti, 2015.

\section{CONCLUSIONS AND SUGGESTION}

\section{A. Conclusion}

The DER variable has no effect on the Yield to Maturity of corporate bonds traded on the Indonesia Stock Exchange. The results of this study are not in line with the research hypothesis which states that DER has a positive effect on bond yield.

$>$ The Maturity Period variable has a positive and significant effect on the Yield to Maturity of corporate bonds traded on the Indonesia Stock Exchange. The 
positive relationship between maturity and Yield To Maturity is due to the longer the maturity period, the higher the risk of bonds, so that investors will signal a greater Yield To Maturity. The results of this study are in line with the research hypothesis which states that Maturity has a positive effect on bond yields

$>$ The firm size variable has a significant negative effect on the Yield To Maturity of corporate bonds traded on the Indonesia Stock Exchange. The results indicate that if the company has large total assets, then the company will offer low or small bond yields, because large-scale companies have less risk compared to small companies that have large risks, besides large companies have better prospects. both in a relatively long period of time, more stable and more able to generate profits than companies with small total assets (Ibrahim, 2008). The results of this study are in line with the research hypothesis which states that firm size has a negative effect on bond yield.

$>$ The Bond Rating variable has a negative and significant effect on the yield of corporate bonds traded on the Indonesia Stock Exchange. Related to the signaling theory, the published bond rating is expected to be a signal about the condition of the bonds issued by the company. Judging from the Asymmetric Information theory, bond ratings also play a role in reducing information asymmetry where investors need information that can be used as a reference in their investment decisions. The results show that the bond rating is considered by investors in making decisions whether the bond is suitable for investment as well as knowing the level of risk and determining the expected YTM amount of corporate bonds . Companies that have low bond ratings will certainly provide high returns to attract investors and compensate for large risks. The results of this study are in line with the research hypothesis which states that bond rating has a negative effect on bond yield

\section{B. Suggestions}

Based on the results of this study, the following suggestions can be made:

$>$ For companies, it is necessary to improve the performance and rating of bonds to maintain investor confidence.

$>$ Companies with large assets find it easier to find external sources of funds through the issuance of bonds. This is because both of them are proven to have an effect on corporate bond YTM.

$>$ Changing the type of bonds in research, for example using government bonds, increasing the number of the study population and extending the period used in the study.

Adding other internal independent variables such as coupons or variables other than DER which can be taken from the company's financial statements such as Current Ratio or so on. Or you can use the company's external variables such as inflation, interest rates and so on. so that it can be a consideration for investors who will invest in bonds. In addition, further researchers can use a cross section data model apart from the panel data regression model.

\section{REFERENCES}

[1]. Aisah, Siti Hatanty and Mulyo Haryanto. (2012). " Analysis of Factors Affecting Corporate Bond Yield (Case Study of All Bond Issuing Companies Registered on the Indonesia Stock Exchange in the 2010-2012 Period." Diponegoro Journal of Accounting. Vol 1, No.1, pp: 2. ISSN (Online): 2337 -3792.

[2]. Arifuddin, Hermawan, Nur Anissa, and Meta Kusumaningtyas. (2014). " The Effect of Corporate Governance, Debt To Equity Ratio, Bond Ratings, and SBI Interest Rates on Bonds to Maturity ". Journal of Management and Accounting PRESTASI, Vol. 13, No.2, pp: 1411-1497.

[3]. Baker, Kent H. and Sattar A. Mansi. (2001). " Assesing Credit Rating Agencies by BondIssuers and Institutional Investors ". Working paper.

[4]. Brigham, Eugene F and Houston. (2006). Fundamental of Financial Management: Fundamentals of Financial Management . Issue $10 . \quad$ Salemba Empat. Jakarta.

[5]. Indonesian Stock Exchange. 2018. www.idx.co.id (accessed May 22, 2019 at 18:45.

[6]. Che-Yahya, Norliza, Ruzita Abdul-Rahim, Rasidah Mohd-Rashid. (2016). " Determinant of Corporate Bond Yield: The Case of the Malaysian Bond Market ". International Journal of Business and Society, Vol. 17, No. 2, PP: 245-258.

[7]. Desnitasari, Isnaini. (2014). "Influence of Interest Rates, Bond Ratings, Company Size and Debt To Equity Ratio Against Yield To Maturity of Corporate Bonds Listed on the Indonesia Stock Exchange Period 2010-2012 ". Telkom University Telecommunications and Informatics Business Management Study Program .

[8]. Fabozzi, Frank J. (2000). Investment Management. Book Two. Salemba Empat. Pearson Education Asia Pte. Ltd. Prentice-Hall.

[9]. Grandes, Martin and Marcel Peter. (2017). " The Determinants of Corporate Bonds Yield Spreads in South Africa: Firm-Specific or Driven by Sovereign Risk?"

[10]. Hapsari, Riska Ayu. (2013). " Yield To Maturity (YTM) Review of Bonds in Corporate Companies ". Accounting Analysis Journal 2 (1) (2013). ISSN 2252-6765.

[11]. Ibrahim, Hadiasman. (2008). " Effect of Interest Rates, Bond Ratings, Company Size, and DER on Yield To Maturity of Corporate Bonds on the Indonesia Stock Exchange for the Period 2004-2006". Diponegoro University. Semarang. 
[12]. Indarsih, Nanik. (2013). " The Effect of SBI Interest Rates, Ratings, Liquidity and Maturity on Yield to Maturity ". Journal of Management Sciences, Volume 1 pp. 125-136 January 1, 2013.

[13]. Rahardjo, Sapto. (2003). Bond Investment Guide . Gramedia Main Library. Jakarta.

[14]. Sari, Ni Wayan Linda Naluritha and Nyoman Abundanti. (2015). " Variables That Affect Bond Yield in Companies Listed on the Indonesia Stock Exchange ". Eud Management E-Journal, Vol. 4, No. 11, pp: 3796-3824. ISNN: 2302-8912.

[15]. Septyawanti, Hilda Indria. (2013). " Factors That Affect Company Bond Ratings ". Accounting Analysis Journal 2 (3) ISSN 2252 - 6765.

[16]. Surya, Artha Budhi and Teguh Gunawan Nasher. (2011). " Analysis of the Effect of SBI Interest Rate, Exchange Rate, Company Size, Debt to Equity Ratio and Bonds on Yields of Corporate Bonds in Indonesia ". School of Business and Management. Bandung Institute of Technology, Vol. 10 No. 2. 